\title{
KEBIJAKAN DISKRIMINATIF DAN KEKERASAN AGAMA
}

\author{
Oleh: Binsar A. Hutabarat \\ Sekolah Tinggi Teologi Reformed Injili Internasional
}

\begin{abstract}
Abstrak
Artikel yang berjudul "Kebijakan Diskriminatif dan Kekerasan Agama" ini fokus memaparkan bagaimana kekerasan agama yang terjadi dalam relasi dengan pemerintah, dan bangkitnya agama-agama yang secara bersamaan diikuti bangkitnya radikalisme agama. Kemudian memaparkan mengenai rumusan kebijakan publik terkait agama di Indonesia serta relasinya dengan kekerasan yang dilakukan negara terhadap agama. Setelah itu mengukur kualitas kebijakan publik terkait agama di Indonesia berdasarkan kriteria kebebesan beragama. Temuan penelitian ini adalah bahwa kebijakan diskriminatif agama di Indonesia masih tetap dilestarikan, dan secara langsung dapat dikatakan, pemerintah terbukti melakukan kekerasan agama.

Kata kunci: kekerasan agama, kebijakan diskriminatif, kebangkitan agama-agama.
\end{abstract}

\section{Pendahuluan}

Indonesia adalah masyarakat dengan beragam agama, hampir semua agama besar di dunia, ada di Indonesia, belum lagi jika dikaitkan dengan keberadaan agama-agama budaya yang ada di Indonesia, serta percampuran agama dan kepercayaan. Pantaslah jika Indonesia dijuluki negara persemaian agama-agama. Uniknya, semua agama-agama itu masuk Indonesia dengan cara damai.

Kondisi Indonesia yang amat beragam itu memerlukan proteksi terhadap kebebasan beragama. Indonesia membutuhkan kebijakan unggul agar kehidupan publik agama-agama berlangsung dengan damai. Kebijakan terkait agama yang unggul dan non-diskriminatif memungkinkan hubungan antara pemerintah dan agama, antaragama, dan internal agama dapat tertata dengan baik, hidup dalam kerukunan. Sebaliknya, hadirnya kebijakan-kebijakan yang buruk dan diskriminatif akan menyebabkan timbulnya ketidakadilan, yang akhirnya bermuara pada konflik antaragama dan pemerintah, antaragama, dan internal agama. Apabila pemerintah Indonesia gagal membuat kebijakan yang unggul dalam bidang kehidupan antaragama di Indonesia, maka taruhannya adalah disintegrasi bangsa yang mengancam keutuhan bangsa Indonesia.

Kebijakan yang diskriminatif akan berdampak panjang, yakni kian menipisnya toleransi antarumat beragama di Indonesia. Indonesia hanya bisa menjadi bangsa yang toleran dan terus memelihara toleransi antaragama jika kebijakan yang dihasilkan terkait dengan kehidupan bersama agama-agama adalah kebijakan-kebijakan yang unggul, dan pastilah kebijakan tersebut 
dapat diimplementasikan. ${ }^{1}$ Hadirnya kekerasan agama sesungguhnya menjadi alarm bagi pemerintah bahwa kebijakan terkait agama perlu ditinjau kembali.

\section{Wajah Ganda Agama}

Tesis kematian pelan-pelan dan bertahap dari agama dalam dunia modern dikumandangkan jauh sejak Zaman Pencerahan. Mereka yang mendeklarasikan kematian agama itu bukan hanya tokoh-tokoh filsafat yang antiagama, tapi juga tokoh-tokoh antropologi, dan psikologi, "bahwa khayalan-khayalan teologis, ritual liturgis simbolis, dan praktik-praktik sakral adalah produk masa lalu yang akan memudar dalam masa modern". ${ }^{2}$ Ippa Norris dan Ronald Inglehart menjelaskan: Matinya agama merupakan keyakinan yang luas diterima dalam ilmu-ilmu sosial selama sebagian besar abad ke-20; tak diragukan, hal itu telah dianggap sebagai model utama dari penelitian sosiologis, di mana sekularisasi disejajarkan dengan birokratisasi, rasionalisasi, dan urbanisasi sebagai revolusi-revolusi historis utama yang mengubah masyarakat agraris lama menjadi masyarakat industri modern. ${ }^{3}$

Senada dengan hal itu, C. Wright Mills menjelaskan mengenai proses kematian agama ini seperti berikut: "Dunia pernah dipenuhi dengan yang-sakral-dalam pemikiran praktik, dan bentuk kelembagaan. Setelah Reformasi dan Renaisans kekuatan-kekuatan modernisasi menyapu dunia, dan sekularisasi, sebagai proses historis yang mengikutinya, memperlemah dominasi dari yang sakral. Pada waktunya, yang sakral sepenuhnya menghilang, kecuali mungkin dalam wilayah pribadi". 4

Berpijak pada tesis kematian agama itulah ketika Perang Dingin berakhir, Francis Fukuyama mendeklarasikan, bahwa demokrasi liberal sekuler merupakan sistem politik terbaik yang bisa dicapai manusia. ${ }^{5}$ Tesis kematian pelan-pelan dan bertahap dari agama tersebut ternyata tidak didukung bukti yang kuat. Munculnya spiritualitas New Age yang melanda dunia hingga ke Indonesia. Kebangkitan gerakan fundamentalisme agama, hingga munculnya kembali partai-partai keagamaan demikian juga di Indonesia membuktikan bahwa agama tidak pernah mati. Peter L. Berger, salah seorang pendukung teori sekularisasi selama 19660-an, secara dramatis menarik kembali klaim-klaim awalnya: "Dunia sekarang ini dengan beberapa pengecualian, ... amat sangat religius sebagaimana sebelumnya, dan di beberapa wilayah bahkan lebih religius ketimbang

$1 \quad$ Riant Nugroho, Public Policy (Jakarta: PT Gramedia, 2009), 39.

${ }^{2}$ Ippa Norris dan Ronald Inglehart. Sekularisasi (Jakarta: Yayasan Abad Demokrasi, 2011), 3.

3 Ibid.

${ }^{4}$ Ibid.

${ }^{5}$ Francis Fukuyama, The End of History and the Last Man (New York: Avon Books, 1992), 338. 
sebelumnya. Hal ini berarti bahwa keseluruhan kepustakaan oleh para sejarawan dan ilmuwan sosial yang secara longgar disebut teori sekularisasi pada dasarnya salah."

Selaras dengan Berger, Rodney Stark dan Roger Finke berujar, "Setelah hampir tiga abad melakukan ramalan yang sama sekali salah, dan salah menafsirkan baik masa kini dan masa lalu, sekaranglah saatnya untuk menguburkan doktrin sekularisasi dalam makam teori-teori yang salah, dan mendoakannya agar doktrin itu "beristirahat dengan tenang."

Kekerasan agama adalah realitas pada banyak negara. Negara sekuler yang mendasari pandangannya pada keyakinan bahwa pelan-pelan agama akan kehilangan perngaruhnya sesungguhnya tidak didukung bukti yang kuat itu terbukti telah mendiskriminasikan agama. Padahal, hingga saat ini agama terus memiliki pengaruh dalam kehidupan pribadi dan masyarakat. Munculnya spiritualitas New Age yang melanda dunia hingga ke Indonesia. Kebangkitan gerakan fundamentalisme agama, hingga munculnya kembali partai-partai keagamaan demikian juga di Indonesia membuktikan bahwa agama tidak pernah mati.

Setelah Perang Dingin, yang terjadi adalah sebaliknya, agama menjadi salah satu kekuatan paling penting dalam politik internasional, entah untuk menjadi lebih baik atau lebih buruk. Manifestasi agama dalam ruang publik saat ini bisa menimbulkan konflik-konflik dan memperdalam perpecahan sosial. Casanova menjelaskan bahwa selama dekade 1980-an, hampir mustahil menemukan konflik politik serius di seluruh dunia yang di belakangnya tidak mengandung "tangan agama". Di Timur Tengah, semua agama dan fundamentalisme wilayah Yahudi, Kristen, dan Muslim - yang dipenuhi oleh pertarungan kekuatan lama, saling bertemu di dalam perang-perang sipil dan bukan sipil. Permusuhan lama antara berbagai agama-agama dunia dan antara cabang-cabang dari agama yang sama berkobar lagi dari Irlandia Utara sampai Yugoslavia, dari India sampai Uni Soviet. ${ }^{8}$

Gilles Kepel tidak berbeda dengan Casanova menyimpulkan bahwa sejarah gerakangerakan kebangkitan modern Yudaisme, kekristenan, dan Islam sebagai The Revenge of God. ${ }^{9}$ Kepel menganalisis revolusi Islam gaya Ayatollah Khomeini di Iran, Zionisme militan Israel dari Gush Emunim, gerakan orang awam Katolik yang sangat dipolitisir di Italia, dan Moral Majority yang didukung oleh fundamentalisme Protestan di Amerika Serikat. Bagi Kepel, semua gerakan ini memanggil orang-orang untuk kembali kepada Tuhan dan menolak sekularisasi dan modernisme.

\footnotetext{
6"Publik dari hampir semua masyarakat industri maju telah bergerakn ke arah orientasi yang lebih sekuler selama 50 tahun terakhir. Meskipun demikian, secara keseluruhan, di dunia sekarang ini, terdapat lebih banyak orang dengan pandangan keagamaan tradisional dibanding sebelumnya, dan mereka merupakan bagian dari populasi dunia yang terus bertambah.’'Ippa Norris dan Ronald Inglehart. Sekularisasi (Jakarta: Yayasan Abad Demokrasi, 2011), 6. ${ }^{7}$ Ibid., 4.

${ }^{8}$ Benyamin F. Intan, Public Religion (New York: Peter Lang, 2006), 13. Samuel P. Huntington, The Clash of Civilizations and the Remaking of World Order (New York: Simon \& Schuster, 1996), 24. ${ }^{9}$ Ibid.
} 
Dalam dunia akademis, Samuel Huntington mengajukan hipotesis bahwa konflik-konflik di dalam dunia politik pasca-Perang Dingin tidak lagi digerakkan oleh ideologi atau ekonomi, seperti selama Perang Dingin, tetapi oleh sebuah benturan antar-peradaban. ${ }^{10}$ Yang dia maksudkan dengan peradaban-peradaban adalah komunitas-komunitas "yang dibedakan satu sama lain oleh sejarah, bahasa, kebudayaan, tradisi, dan yang paling penting oleh agama." Huntington meramalkan, benturan peradaban "akan mendominasi politik global" dan membuat ide-ide mengenai demokrasi dan hak-hak asasi manusia di luar pantai-pantai Barat tidak bisa berkembang. ${ }^{11}$ Jika itu benar, agama di dalam kehidupan publik pastilah sesuatu yang sangat berbahaya. Tidak mengherankan, hipotesis Huntington banyak diperdebatkan, khususnya di dalam Konfusianisme dan Islam, dua agama yang dianggap bermusuhan dengan Barat. ${ }^{12}$

Penggambaran-penggambaran tentang agama yang penuh kekerasan dan tidak toleran sesungguhnya bukanlah gambaran yang lengkap mengenai agama. Casanova berpendapat, selama tahun 1980-an, para aktivis religius juga merupakan para pemain utama dalam gerakan-gerakan yang berjuang untuk pembebasan, keadilan, dan demokrasi di seluruh dunia.

Teologia-teologia pembebasan menyebar luas di luar Amerika Latin, dengan mendapatkan bentuk-bentuk dan nama-nama baru, Afrika dan Asia, Protestan dan Yahudi, orang kulit hitam dan feminis. Dengan runtuhnya sosialisme, teologia pembebasan tampaknya merupakan satu-satunya cap "internasional" yang masih tersisa. ${ }^{13}$ R. Scott Appleby juga menekankan banyak gerakan religius mutakhir dengan agenda yang sama untuk mendukung keadilan, toleransi, dan perdamaian. ${ }^{14}$

\section{Kebijakan Publik Agama}

Makna kata "kebijakan" harus dipahami dalam konteks historis, makna kebijakan yang senantiasa berubah menunjukkan perubahan-perubahan dalam praktik kebijakan. Pada awalnya istilah "kebijakan" atau pokok-pokok platform menjadi rasionalitas politik. Mempunyai kebijakan berarti memiliki alasan atau argumen yang mengandung klaim bahwa pemilik kebijakan memahami persoalan beserta solusinya. Kebijakan dalam hal ini mengemukakan apa yang sedang terjadi dan apa yang seharusnya dilakukan. Artinya, sebuah kebijakan memberikan semacam teori yang mendasari klaim legitimasi. Selanjutnya, dengan berkembangnya sistem partai dan pemilu modern di masyarakat industri, diskursus kebijakan kemudian menjadi sarana utama bagi elektorat untuk terlibat dalam kegiatan "politik" dan persaingan elite politik. Politisi diharapkan punya

\footnotetext{
${ }^{10}$ Ibid.

${ }^{11}$ Ibid.

${ }^{12}$ Ibid.

${ }^{13}$ Untuk reaksi yang rinci terhadap idea Huntington mengenai "benturan antar peradaban" di dalam konteks Asia dan Indonesia, lihat Salim Rashid, ed., The Clash of Civilizations? Asian Responses( Karachi: Oxford University Press, 1997), M. Nasir Tamara dan Elza Peldi Taher, eds., Agama dan Dialog Antara Peradaban [Religion and The Dialogue between Civilizations] (Jakarta: Penerbit Paramadina, 1996).

${ }^{14}$ Casanova, Public Religions, 3.
} 
"kebijakan" sebagaimana halnya sebuah toko mesti mempunyai barang dagangan. Kebijakan merupakan "mata uang" penting dalam perdagangan demokratik. ${ }^{15}$

Gagasan kebijakan sebagai "produk" atau "prinsip" kemudian berkembang menjadi istilah dalam konotasi netral seperti dinyatakan oleh Lasswell: "Kata 'kebijakan' (policy) umumya dipakai untuk menunjukkan pilihan terpenting yang diambil baik dalam kehidupan organisasi atau privat." "Jadi Lasswell tidak membatasi penggunaan istilah kebijakan hanya dalam area politik saja, menurutnya, "Kebijakan" bebas dari konotasi yang dicakup dalam kata politis (political) yang sering kali diyakini mengandung makna "keberpihakan" dan korupsi.".17

Menurut Tilaar dan Nugroho istilah kebijakan publik mempunyai banyak pemahaman teoritis ${ }^{18}$, yang dirumuskannya demikian:

Kebijakan publik adalah keputusan yang dibuat oleh negara, khususnya pemerintah, sebagai strategi untuk merealisasikan tujuan dari negara yang bersangkutan.Kebijakan publik adalah strategi untuk mengantar masyarakat pada masa awal, memasuki masyarakat transisi, untuk menuju kepada masyarakat yang dicita-citakan. ${ }^{19}$

Berdasarkan definisi di atas jelaslah bawa kebijakan publik merupakan upaya yang dilakukan pemerintah untuk menyelesaikan permasalahan publik. Thomas R. Dye merangkum dari definisidefinisi mengenai kebijakan publik demikian: "Public policyis whatever governments choose to do or not to do"20 (kebijakan publik adalah apapun pilihan pemerintah untuk melakukan sesuatu atau tidak melakukan). ${ }^{21}$ Bagi Dye, pusat perhatian kebijakan publik tidak hanya pada apa yang dilakukan pemerintah, melainkan termasuk juga apa saja yang tidak dilakukan oleh pemerintah. Karena hal-hal yang tidak dilakukan pemerintah mempunyai dampak yang cukup besar terhadap masyarakat seperti halnya dengan tindakan-tindakan yang tidak dilakukan oleh pemerintah. ${ }^{22}$

\footnotetext{
$15 \quad$ Ibid., 16.

$16 \quad$ Ibid., 17.

$17 \quad$ Ibid., 17.

18 H.A.R. Tilaar dan Rian Nugroho, Kebijakan Pendidikan (Yogyakarta: Pustaka pelajar, 2009), 183-4.

$19 \quad$ Ibid., 184-5.

20 Thomas R. Dye, Understanding Public Policy (United States: Prentice Hall, 1978), 1. Thomas Dye menjelaskan, More elaborate definition of public policy are found in literature, of course, but on examination they seam to boil down to the same thing. David Easton defines public policy as "the othoritative allocation of values for the whole society" but it turns out that only the government can authoritatively act on the whole society, and everythingthe government choose to do or not to do results in the whole allocation of values. Laswell and Kaplan defines policy "as a projected program of goals, value, and pravtices. "and Carl Friedrich says, it is essencial.

$21 \quad$ Ibid., 35.

22 Lihat, Irawan Suntoro dan Hasan Hariri, Kebijakan Publik (Yogyakarta: Graha Ilmu, 2015$), 3$.
} 
Berdasarkan definisi-definisi di atas, jelaslah bahwa kebijakan publik mempunyai beberapa implikasi sebagaimana ditegaskan Anderson, kebijakan publik berorientasi pada maksud atau tujuan, bukan perilaku serampangan. Kebijakan publik bukan sesuatu yang berlaku begitu saja, melainkan direncanakan oleh aktor-aktor politik yang terlibat dalam sistem politik. Kebijakan merupakan arah atau pola tindakan yang dilakukan oleh pejabat-pejabat pemerintah, bukan merupakan keputusan-keputusan tersendiri. Suatu kebijakan mencakup tidak hanya keputusan untuk menetapkan undang-undang mengenai suatu hal, tetapi juga keputusan-keputusan beserta dengan pelaksanaannya. Dan kebijakan adalah apa yang sebenarnya dilakukan oleh pemerintah dalam mengatur persoalan-persoalan publik misalnya terkait dengan kehidupan beragama, demikian juga perihal pendirian rumah ibadah. Kebijakan publik mungkin dalam bentuknya bersifat positif dan negatif. Secara positif, kebijakan, mungkin mencakup bentuk tindakan pemerintah yang jelas untuk untuk mempengaruhi suatu masalah tertentu. Secara negatif, kebijakan mungkin mencakup suatu keputusan oleh pejabat-pejabat pemerintah, tetapi tidak untuk mengambil keputusan tindakan dan tidak untuk melakukan sesuatu mengenai suatu persoalan yang memerlukan keterlibatan pemerintah. Dengan kata lain, pemerintah dapat mengambil kebijakan untuk tidak melakukan campur tangan dalam bidang-bidang umum maupun khusus. Kebijakan tidak campur tangan mungkin mempunyai konsekuensi-konsekuensi besar terhadap masyarakat atau kelompok-kelompok masyarakat. Dalam bentuknya yang positif, kebijakan publik didasarkan pada undang-undang dan bersifat otoritatif. ${ }^{23}$

Kebijakan publik ini adalah jalan bagi pemerintah Indonesia untuk mencapai apa yang dicita-citakan seluruh rakyat Indonesia, yaitu terwujudnya suatu masyarakat yang adil dan makmur. Sedang dalam bidang kehidupan beragama, kebijakan publik adalah pedoman bagaimana negara mencapai apa yang diperintahkan Pasal 29 UUD 1945 tentang Kebebasan Beragama. (1) Negara berdasar atas Ketuhanan Yang Maha Esa. (2) Negara menjamin kemerdekaan tiap-tiap penduduk untuk memeluk agamanya masing-masing dan untuk beribadat menurut agamanya dan kepercayaannya itu. Pemerintah mendapatkan mandat rakyat untuk memberikan proteksi terhadap kebebasan beragama, kebebasan beribadat baik secara pribadi maupun secara berkelompok dalam sebuah rumah ibadat.

Kebijakan perlindungan terhadap kebebasan beragama dan berkeyakinan secara tegas ditetapkan dalam UUD RI. Kebijakan tersebut mesti menjadi pedoman bagi peraturan-peraturan di bawahnya. Kebijakan perlindungan kebebasan beragama secara langsung mensyaratkan adanya hak kebebasan mendirikan rumah ibadah sesuai dengan agama dan kepercayaan. Hak menjalankan ibadah dan mendirikan rumah ibadah ini tergolong kategori hak yang dapat dibatasi (derogable right). Pembatasan tersebut menurut Deklarasi Universal HAM pasal 18 ayat (2) berbunyi seperti berikut: 
Kebebasan menjalankan dan menentukan agama atau kepercayaan seseorang hanya dapat dibatasi oleh ketentuan berdasarkan hukum, dan yang diperlukan untuk melindungi keamanan, ketertiban, kesehatan, atau moral masyarakat, atau hak-hak kebebasan mendasar orang lain. Perserikatan Bangsa-Bangsa secara khusus menjamin adanya perlindungan atas rumah-rumah ibadah yang digunakan oleh warga. Hak untuk membangun rumah ibadah merupakan perwujudan dari kebebasan beragama atau berkeyakinan, sebagaimana hak untuk menggunakan dan memasang simbol agama/keyakinan, dan menjalankan hari libur keagamaan/keyakinan. ${ }^{24}$

Selain dokumen DUHAM 1948, Kovenan Internasional Hak-Hak Sipil dan Politik, ada dua dokumen lain yang dideklarasikan PBB, dan dokumen-dokumen tersebut menyediakan standarstandar internasional yang diakui secara luas, serta dapat digunakan sebagai rujukan untuk menyelesaikan masalah-masalah HAM terkait agama.

Pertama adalah dokumen Deklarasi untuk Mengeliminasi Segala Bentuk Praktik Intolernasi dan Diskriminasi Berdasarkan Agama dan Kepercayaan (Declaration on Elimination of All Forms Intolerance and Discrimination Based on Religion or Belief).Pasal 2 Deklarasi ini mewajibkan negara untuk mengambil tindakan efektif dalam mencegah atau menghapus praktik diskriminasi berbasis agama dan keyakinan. Bahkan negara juga memiliki kewajiban untuk membatalkan setiap produk perundang-undangan yang berisi pesan diskriminasi.

Kedua, dokumen Deklarasi untuk Melindungi Hak-Hak Individu Minoritas untuk Bidang Nasionalitas/Etnis, Agama, dan Bahasa (Declaration on the Rights of Persons Belonging to National or Ethnic, Religious and Linguistic Minorities). Pasal 4 ayat (2) Deklarasi tersebut menyatakan negara juga berkewajiban untuk memberikan perlindungan bagi individu-individu minoritas agar mereka bisa menjalankan ritual agamanya dengan bebas. Negara juga berkewajiban untuk mengambil tindakan efektif untuk menciptakan iklim kondusif agar individu-individu minoritas dapat menjalankan ibadahnya dengan baik. ${ }^{25}$

\section{Indikator Adanya Kekerasan Agama dalam Kebijakan Publik}

Pengukuran terhadap tingkat kekerasan agama yang dilakukan pemerintah dalam kajian ini menggunakan standar atau kriteria yang dimuat dalam Laporan Departemen Luar Negeri kebebasan beragama yang dikembangkan berdasarkan 20 kriteria yang dimuat dalam laporan Departemen Luar Negeri Amerika Serikat tentang Kebebasan Keagamaan Internasional, 2002. ${ }^{26}$

\footnotetext{
$24 \quad$ Ibid. 19.

$25 \quad$ Ibid. 20

${ }^{26}$ Pippa Noris dan Ronald Inglehart, Sekularisme, 299-300
} 
Skala tersebut mewakili versi yang diperluas dari skala Chaves dan Cann1992 yang digunakan untuk mengukur peraturan negara dalam 18 masyarakat pasca-industri. 1. Konstitusi membatasi kebebasan beragama. 2. Konstitusi tidak mengakui kebebasan beragama. (Atau hukum tidak mengakui kebebasan beragama, dalam sebuah negara yang tidak memiliki konstitusi tertulis). 3. Terdapat sebuah gereja resmi negara. 4. Negara mendukung satu agama. 5. Organisasiorganisasi keagamaan harus mendaftar pada negara atau disahkan oleh negara untuk bisa beroperasi secara legal, atau pemerintah memberlakukan berbagai kekangan pada organisasiorganisasi yang tidak terdaftar atau diakui. 6. Negara mengeluarkan izin hukum bagi bangunanbangunan keagamaan. 7. Negara mengangkat atau menyetujui para pemimpin gereja, para pemimpin gereja mengangkat atau menyetujui para pejabat pemerintah, dan/atau para pemimpin gereja memiliki posisi khusus dalam pemerintahan. 8. Negara memberikan gaji gereja secara langsung. 9. Negara mensubsidi beberapa/semua gereja. 10. Negara memberikan potongan pajak bagi beberapa/semua gereja. 11. Negara melarang pendeta/pemimpin agama dari semua/beberapa agama tertentu untuk memegang jabatan publik. 12. Negara memiliki sebagian properti dan bangunan-bangunan gereja. 13. Negara memerintahkan pendidikan keagamaan di sekolahsekolah negara, meskipun pelajar dapat dibebaskan dari kewajiban ini dengan permintaan orangtua.14. Ada laporan-laporan tentang konversi keagamaan yang dipaksakan. 15. Negara melarang beberapa kelompok keagamaan, perkumpulan keagamaan, atau sekte. 16. Negara mengekang/melarang para misionaris memasuki negara tersebut untuk tujuan-tujuan menarik pemeluk baru. 17. Negara mengekang/menyensor beberapa kepustakaan keagamaan yang masuk atau beredar di negara tersebut. 18. Negara memenjarakan atau menahan beberapa kelompok keagamaan atau individuindividu. 19. Negara gagal mencegah konflik-konflik dan kekerasan etnoreligius yang serius yang dilakukan terhadap beberapa ke lompok minoritas. 20. Negara tersebut disebut sebuah negara khusus dalam hal kebebasan beragama oleh Departemen Luar Negeri Amerika Serikat. ${ }^{27}$

\section{Kebijakan diskriminatif terkait agama di Indonesia}

\section{a. Kebijakan tentang Penodaan Agama}

Pembatasan jumlah agama di Indonesia tidak memiliki pijakan dalam perundang-undangan. Namun, pendefinisan agama menurut Departemen Agama yang memiliki syarat-syarat berikut: memiliki kitab suci, memiliki Nabi, percaya akan satu Tuhan (Ketuhanan yang Maha Esa), memiliki tata ibadah bagi pengikutnya, telah diartikan sebagai pembatasan jumlah agama. Keberadaan agama-agama lain seperti Yahudi, Shinto, Zaratustarian, Taoisme tidak dilarang di Indonesia. Anehnya, agama-agama suku yang adalah agama pertama penduduk Indonesia tidak diakui keberadaannya dan mereka wajib bergabung pada salah satu agama resmi negara, jika tidak akan kehilangan hak-hak sipilnya. Daerah di mana penganut agama-agama suku itu tinggal

${ }^{27}$ Ibid., 
menjadi ladang misi agama-agama resmi, sedang daerah di mana penganut agama resmi menjadi tempat terlarang bagi misi agama-agama lain.

Pemberlakuan agama resmi sebagaimana dilakukan pada masa Soekarno juga terjadi pada masa Orde Baru. Bahkan yang lebih tragis, agama Konghucu pada masa Soeharto tidak diakui keberadaannya sebagai agama resmi melalui Penetapan Presiden No. 1/Pn.ps/1965, dan dalam Undang-Undang No. 5 Tahun 1969 tentang Jenis-jenis Agama di Indonesia yang terdiri atas, Islam, Katolik, Kristen Protestan, Hindu, Buddha, Konghucu, tidak lagi diakui pada masa Soeharto melalui Surat Edaran (SE) Menteri Dalam Negeri No. 477/74054/BA.01.2/4683/95, tanggal 18 November 1978 yang menyatakan agama yang diakui pemerintah adalah, Islam, Kristen, Katolik, Hindu dan Buddha. ${ }^{28}$ Umat Konghucu Indonesia baru kembali diakui keberadaannya pada masa pemerintahan Presiden Abdurrahman Wahid. Namun, aliran kepercayaan dan agama-agama suku sampai saat ini tetap mengalami pemasungan karena tidak pernah diakui eksistensinya sebagai agama.

Surat Keputusan (SK) Menteri Agama dan Menteri Dalam Negeri Nomor: 01/BER/MDNMAG/1969 tentang Pelaksanaan Tugas Aparatur Pemerintahan dalam Menjamin Ketertiban dan Kelancaran Pelaksanaan Pengembangan dan Ibadat Agama oleh Pemeluk-pemeluknya. Dalam pasal 4 ayat 1 perundang-undangan tersebut dijelaskan bahwa pendirian rumah ibadah perlu mendapat ijin dari kepala daerah atau pejabat pemerintah di bawahnya yang dikuasakan untuk itu. Pada praktiknya SK-SK bersama mengenai peraturan untuk mendirikan rumah ibadah hanya mengatur pendirian rumah ibadah untuk orang Kristen. ${ }^{29}$ Karena memang latar belakang dikeluarkannya SK tersebut karena ada gejala- gejala bahwa dalam beberapa daerah, umat Kristen bertambah dengan pesat, dan di beberapa daerah terdapat perusakan terhadap gedung gereja. ${ }^{\mathbf{3 0}}$ Ketetapan bahwa negara menjamin kebebasan warga negara untuk beribadah menurut kepercayaannya masing-masing telah disangkal dengan keluarnya SKB tahun 1969 itu. SKB ini menjadi alasan bagi penutupan, bahkan perusakan disertai pembakaran terhadap rumah-rumah ibadah agama minoritas.

SKB Dua Menteri ini pada masa reformasi mengalami perubahan menjadi Peraturan Bersama Menteri (PBM) dalam Peraturam Bersama Menteri Agama dan Menteri Dalam Negeri Nomor 9 Tahun 2006, dan Nomor 8 Tahun 2006. Namun, inti dari PBM tersebut tidak berbeda dari SKB yang terindikasi memuat pasal-pasal yang membatasi kebebasan beragama, khususnya pembangunan tempat ibadah yang menuntut adanya sejumlah 60 tanda tangan orang dewasa dari aggota masyarakat di mana tempat ibadah itu akan didirikan. Untuk pendirian gereja, sekurangkurangnya diajukan oleh 90 orang anggota dewasa. ${ }^{31}$ Setelah pemberlakuan PBM, pembakaran,

\footnotetext{
${ }^{28}$ Setiawan, "Konghucu dalam kemajemukan agama-agama" dalam Struggling in Hope, diedit oleh Suleeman,Sutama, Rajendra, h. 463-4.

${ }^{29}$ Simatupang, Membuktikan Ketidakbenaran Suatu Mitos, 240.

${ }^{30}$ Ibid.

${ }^{31}$ Bahan Rapat konsultasi Pimpinan Lembaga Persekutuan Gerejawi Aras nasional Dengan pemerintah Pusat Tentang Implementasi Peraturan bersama No. 9 dan 8 Tahun 2006 (Jakarta, 2008)
} 
perusakan tempat ibadah terus terjadi. Forum Komunikasi Kristen Jakarta mencatat selama 21 Maret 2006 hingga 17 Agustus 2007 terdapat 67 gereja yang mendapat tekanan dan gangguan. ${ }^{32}$ Yang mengherankan, surat keputusan yang kontroversial dan tidak produktif ini tidak juga dibatalkan. Arti penting sebuah rumah ibadah untuk menjalankan ibadah secara bersama-sama itulah yang membuat pemerintah Indonesia pada awalnya tidak mewajibkan pengurusan ijin pendirian rumah ibadah, apalagi pada awalnya daerah-daerah di Indonesia umumnya bersifat homogen. Namun, dengan berjalannya waktu, dan perpindahan penduduk yang makin tinggi, maka daerah-daerah di Indonesia menjadi lebih heterogen, dan hadirlah persoalan terkait dengan pendirian rumah ibadah.

Untuk mengatasi konflik tentang pendirian rumah ibadah pemerintah Indonesia mengeluarkan peraturan tentang pendirian rumah ibadah. Peraturan tentang pendirian rumah ibadah ini pertama kali dikeluarkan pada tahun 1969 dalam bentuk Surat Keputusan Bersama (SKB) Menteri Agama dan Menteri Dalam Negeri Nomor 01/BER/MDN/1969 tentang Pelaksanaan Tugas Aparatur Pemerintahan dalam Menjamin Ketertiban dan Kelancaran Pelaksanaan Pengembangan dan Ibadat oleh Pemeluk-pemeluknya.

Terbitnya SKB tersebut ternyata kemudian dijadikan instrumen bagi penutupan gereja di berbagai tempat. Dengan alasan itu kemudian pemerintah merevisi SKB tersebut menjadi PBM No. 9/2006 dan 8/2006 dan di dalamnya juga mengatur pendirian rumah ibadah. PBM memang memiliki perbedaan dengan SKB, namun keduanya memiliki persamaan, yakni mensyaratkan keharusan pengurusan ijin rumah ibadah.

\section{b. Kebijakan Penyiaran Agama}

Menteri Agama dan Menteri Dalam Negeri juga membuat keputusan bersama nomor 1 tahun 1979 tentang tata cara pelaksanaan penyiaran agama dan bantuan luar negeri kepada lembaga keagamaan di Indonesia. Pasal 4 dari keputusan tersebut menjelaskan bahwa penyiaran agama tidak dibenarkan bagi orang atau kelompok orang yang telah memeluk/menganut agama lain. $^{33}$

Perundang-undangan yang diskriminatif juga menyasar aliran Ahmadiyah. Menteri Agama dan Jaksa Agung dan Menteri Dalam Negeri mengeluarkan SKB yang mengatur jemaat Ahmadiyah dan aktivitasnya. SKB tersebut memang tidak membubarkan aliran Ahmadiyah, namun melarang penyebaran Ahmadiyah, meski masyarakat banyak yang mengartikannya sebagai pembubaran Ahmadiyah, sehingga setelah keluarnya keputusan itu tanggal 9 Juni 2008, pemeluk Ahmadiyah mengalami ancaman.

\footnotetext{
${ }^{32}$ Komnas HAM: Stop Penutupan Gereja (Sinar Harapan 15/1/2008).

${ }^{33}$ Josephus A. Suatan, Tinjauan Terhadap Materi Peraturan tentang Kehidupan Beragama, (Litbang Jawa Barat, tidak diterbitkan untuk umum, tanpa tahun)
} 
Direktur Jenderal Hak Asasi manusia (HAM) Harkristuti menduga SKB yang mengatur jemaat Ahmadiyah dan aktivitasnya diterbitkan setelah ada demonstrasi besar yang dilakukan sejumlah ormas di antaranya Hizbut Tahir (HTI), Gerakan Pemuda Kabah (GPK), Laskar Aswajah, Aliansi Damai Antipenistaan Islam, dan Forum Betawi Rempug (FBR) di istana kepresidenan yang meminta agar Ahmadiyah di bubarkan. ${ }^{34} \mathrm{Jadi}$ jelaslah, lahirnya produk undang-undang yang diskriminatif terkait ketidakkonsistenan pemerintah demi mencari posisi aman untuk tetap terus berkuasa.

\section{c. Perda-perda agama}

Produk undang-undang diskriminatif tidak hanya hadir melalui pusat pemerintahan, tetapi juga melalui pemerintahan lokal. Peraturan daerah (Perda) yang berbasis agama muncul di berbagai daerah, awalnya pada daerah-daerah di mana Islam menjadi mayoritas, itulah sebabnya perda-perda agama itu populer dengan sebutan Perda Syariat.

Maraknya penerapan Perda-perda Syariat di berbagai daerah di Indonesia terutama sejak Provinsi Aceh memberlakukan ketentuan syariat Islam di wilayahnya, setelah mendapatkan otonomi khusus melalui perundang-undangan nasional. Sulawesi Selatan dan Jawa Barat mengikuti jejak Aceh memberlakukan ketentuan Syariat di wilayahnya. ${ }^{35}$ Perda agama ini setidaknya telah diberlakukan di tingkat provinsi (6), Kabupaten (38), Kota (12). ${ }^{36}$

Diskriminasi yang lahir karena penerapan perda agama itu kemudian menimbulkan perlawanan pada daerah-daerah di mana pemeluk agama non Islam yang menjadi mayoritas. Provinsi Bali dengan mayoritas agama Hindu Bali menuntut otonomi khusus sebagaimana yang diberikan pada Provinsi Aceh. Reaksi kontroversial atas perda agama (perda syariat) datang dari wilayah Manokwari, Papua. Munculnya usulan Perda berbasis Injil sebagai proteksi terhadap islamisasi di Papua dari tokoh-tokoh agama Kristen di Papua, yang juga mendapat dukungan masyarakat, serta pemerintah lokal Manokwari mengakibatkan kebebasan beragama menjadi problem serius bukan hanya pada daerah-daerah mayoritas Islam, tapi juga pada daerah-daerah mayoritas Kristen dan juga mayoritas Hindu. ${ }^{37} \mathrm{Hal}$ lain yang tidak kalah pentingnya dalam memberikan andil bagi tingginya kekerasan agama di Indonesia juga berkait dengan ketidakkonsistenan pemerintah dalam berpegang pada konstitusi. Lahirnya Surat Keputusan (SK) Menteri Agama dan Menteri Dalam Negeri Nomor: 01/BER/MDN-MAG/1969 tentang Pelaksanaan Tugas Aparatur Pemerintahan dalam Menjamin Ketertiban dan Kelancaran Pelaksanaan Pengembangan dan Ibadat Agama oleh Pemeluk-pemeluknya, merupakan contoh ketidakkonsisitenan pemerintah yang menghadirkan aturan yang dikriminatif dan bertentangan dengan konstitusi. Menariknya lagi, SK-SK bersama mengenai peraturan untuk mendirikan rumah ibadah hanya mengatur pendirian rumah ibadah untuk orang Kristen. Hal itu semakin jelas ketika

\footnotetext{
${ }^{34}$ Dirjen HAM Sesalkan SKB tentang Ahmadiyah. Sinar Harapan (10/6/2009)

35 Arskal Salim, Perda berbasis Agama dan perlindungan Konstitusional Penegakan HAM(Jurnal Perempuan, I/60)

${ }^{36}$ Reform Review, Proyek Syariahisasi daerah (Vol I, No. 1).

${ }^{37}$ Binsar A. Hutabarat, Perda Agama (Injil) dalam Perspektif Kristiani, (Jurnal Perempuan I/60)
} 
melihat latar belakang dikeluarkannya SK tersebut, yakni karena ada gejala- gejala bahwa dalam beberapa daerah umat Kristen bertambah dengan pesat, dan di beberapa tempat terdapat perusakan terhadap gedung gereja.

Lahirnya UU No. 1/1974 di mana Konghucu tidak tercantum sebagai agama resmi, jelas bertentangan dengan konstitusi Indonesia yang mengakui kebebasan beragama. Apalagi undangundang perkawinan tersebut juga terbukti telah mengekang kebebasan beragama yakni adanya larangan menikah beda agama. Selanjutnya, dalam Instruksi Menteri Agama No. 4/1978 di mana Departemen Agama tidak mengakui aliran kepercayaan, jelas membuktikan bahwa transformasi Pancasila ke dalam aturan-aturan di bawahnya tidak berjalan dengan mulus, banyak aturan di negeri ini yang sesungguhnya bertentangan dengan Pancasila dan UUD 1945. Tidak konsistennya pemerintah dalam berpegang pada konstitusi khususnya terhadap hak kebebasan beragama semakin terlihat jelas dengan kehadiran perda-perda bernuansa agama di berbagai daerah di Indonesia, khususnya pada daerah-daerah di mana agama-agama tertentu menjadi mayoritas. Kehadiran perda-perda diskriminatif tersebut kemudian membuat interdepedensi antaragama makin tergerus, dan intoleransi agama makin menguat di negeri yang terkenal dengan kerukunannya.

Berdasarkan uraian mengenai kebijakan diskriminatif di Indonesiadi atas, maka dapat diukur tingkat kebijakan publik Indonesia terkait agama sebagai berikut:

\section{Skala Kebijakan Terkait Agama di Indonesia}

\begin{tabular}{|l|c|c|}
\hline \multicolumn{1}{|c|}{ Indikator } & $\begin{array}{c}\text { Ya } \\
(\mathbf{1})\end{array}$ & $\begin{array}{c}\text { Tidak } \\
(\mathbf{0})\end{array}$ \\
\hline 1.Konstitusi membatasi kebebasan beragama. & & $\mathbf{0}$ \\
\hline 2. Konstitusi tidak mengakui kebebasan beragama. & & $\mathbf{0}$ \\
\hline 3. Terdapat agama resmi negara. & $\mathbf{1}$ & \\
\hline 4. Negara mendukung satu agama (agama tertentu) & $\mathbf{1}$ & \\
\hline $\begin{array}{l}\text { 5. Organisasi-organisasi keagamaan harus mendaftar pada negara } \\
\text { atau disahkan oleh negara untuk bisa beroperasi secara legal, atau } \\
\text { pemerintah memberlakukan berbagai kekangan pada organisasi- } \\
\text { organisasi yang tidak terdaftar atau diakui. }\end{array}$ & & \\
\hline $\begin{array}{l}\text { 6. Negara mengeluarkan izin hukum bagi bangunan-bangunan } \\
\text { keagamaan. }\end{array}$ & $\mathbf{1}$ & \\
\hline $\begin{array}{l}\text { 7. Negara mengangkat atau menyetujui para pemimpin agama, para } \\
\text { pemimpin agama mengangkat atau menyetujui para pejabat }\end{array}$ & & $\mathbf{0}$ \\
\hline
\end{tabular}




\begin{tabular}{|l|c|c|}
\hline $\begin{array}{l}\text { pemerintah, dan/atau para pemimpin gereja memiliki posisi khusus } \\
\text { dalam pemerintahan. }\end{array}$ & & \\
\hline 8. Negara memberikan gaji pemimpin agama secara langsung. & & $\mathbf{0}$ \\
\hline 9. Negara mensubsidi beberapa/semua agama. & $\mathbf{1}$ & \\
\hline 10. Negara memberikan potongan pajak bagi beberapa/semua agama. & $\mathbf{1}$ & $\mathbf{0}$ \\
\hline $\begin{array}{l}\text { 11. Negara melarang pendeta/pemimpin agama dari semua/beberapa } \\
\text { agama tertentu untuk memegang jabatan publik. }\end{array}$ & $\mathbf{0}$ \\
\hline $\begin{array}{l}\text { 12. Negara memiliki sebagian properti dan bangunan-bangunan } \\
\text { gereja. }\end{array}$ & & \\
\hline $\begin{array}{l}\text { 13. Negara memerintahkan pendidikan keagamaan di sekolahsekolah } \\
\text { negara, meskipun pelajar dapat dibebaskan dari kewajiban ini dengan } \\
\text { permintaan orangtua. }\end{array}$ & $\mathbf{1}$ & \\
\hline $\begin{array}{l}\text { 14. Ada laporan-laporan tentang konversi keagamaan yang } \\
\text { dipaksakan. }\end{array}$ & $\mathbf{1}$ & \\
\hline $\begin{array}{l}\text { 15. Negara melarang beberapa kelompok keagamaan, perkumpulan } \\
\text { keagamaan, atau sekte. }\end{array}$ & $\mathbf{1}$ & \\
\hline $\begin{array}{l}\text { 16. Negara mengekang/melarang para misionaris memasuki negara } \\
\text { tersebut untuk tujuan-tujuan menarik pemeluk baru. }\end{array}$ & $\mathbf{1}$ & \\
\hline $\begin{array}{l}\text { 17. Negara mengekang/menyensor beberapa kepustakaan keagamaan } \\
\text { yang masuk atau beredar di negara tersebut. }\end{array}$ & $\mathbf{1}$ & $\mathbf{0}$ \\
\hline $\begin{array}{l}\text { 18. Negara memenjarakan atau menahan beberapa kelompok } \\
\text { keagamaan atau individu-individu. }\end{array}$ & $\mathbf{1}$ & $\mathbf{7}$ \\
\hline $\begin{array}{l}\text { 19. Negara gagal mencegah konflik-konflik dan kekerasan } \\
\text { etnoreligius yang serius yang dilakukan terhadap beberapa ke lompok } \\
\text { minoritas. }\end{array}$ & $\mathbf{1}$ & $\mathbf{1 3}$ \\
\hline $\begin{array}{l}\text { 20. Negara tersebut disebut sebuah negara khusus dalam hal } \\
\text { kebebasan beragama oleh Departemen Luar Negeri Amerika Serikat. }\end{array}$ & & \\
\hline
\end{tabular}

Berdasarkan tabel di atas dapat diketahui bahwa dari 20 kriteria yang ditetapkan sebagai alat ukur pengakuan terhadap kebebasan beragama, kebijakan di Indonesia mendapatkan skor (13) dari skor maksimal (20), artinya lebih dari 50\% kriteria sebuah negara ditetapkan melakukan kekerasan agama teridentifikasi termuat dalam kebijakan negara. Dengan demikian dapat disimpulkan bahwa kebijakan publik di Indonesia masih berisi kebijakan diskriminatif yang secara langsung mengancam kerukunan hidup antar umat beragama di Indonesia.

\section{Penutup}

Kekerasan agama bisa terjadi karena tindakan pemerintah, yang kemudian berdampak hadirnya kekerasan antaragama dan kekerasan internal agama. Kebijakan terkait agama seharusnya bebas dari diskriminasi agar tercipta toleransi antaragama, internal agama, pemerintah dan agama-agama. Berdasarkan penelitian yang telah dilakukan ditemukan bahwa kebijakan di 
Indonesia masih berisi kebijakan-kebijakan diskriminatif, kebijakan diskriminatif bukan hanya menunjukkan adanya kekerasan yang dilakukan pemerintah terhadap agama, namun secara bersamaan dapat dipegunakan sebagai instrumen oleh agama tertentu untuk menunjukkan hegemoninya yang kemudian bermuara pada kekerasan agama. Berdasarkan penelitian yang dilakukan terlihat bahwa pemerintah Indonesia sepatutnya memperbaiki kualitas kebijakan terkait agama agar dapat menghadirikan kebijakan unggul terkait agama, yakni sebuah kebijakan publik yang non-diskriminatif. Perbaikan kualitas kebijakan memungkinkan kehidupan publik agamaagama akan lebih baik, karena kebijakan publik terkait agama yang unggul akan dapat diimplementasikan untuk menghadirkan kehidupan publik agama-agama yang rukun dan damai.

\section{DAFTAR PUSTAKA}

Arskal Salim, Perda berbasis Agama dan perlindungan Konstitusional Penegakan HAM(Jurnal Perempuan, I/60)

Bahan Rapat konsultasi Pimpinan Lembaga Persekutuan Gerejawi Aras nasional Dengan pemerintah Pusat Tentang Implementasi Peraturan bersama No. 9 dan 8 Tahun 2006 (Jakarta, 2008)

Benyamin F. Intan, Public Religion (New York: Peter Lang, 2006), 13. Samuel P. Huntington, The Clash of Civilizations and the Remaking of World Order (New York: Simon \& Schuster, 1996)

Binsar A. Hutabarat, Perda Agama (Injil) dalam Perspektif Kristiani, (Jurnal Perempuan $\mathrm{I} / 60)$

Dirjen HAM Sesalkan SKB tentang Ahmadiyah. Sinar Harapan (10/6/2009)

Francis Fukuyama, The End of History and the Last Man (New York: Avon Books, 1992) H.A.R. Tilaar dan Rian Nugroho, Kebijakan Pendidikan (Yogyakarta: Pustaka pelajar, 2009),

Irawan Suntoro dan Hasan Hariri, Kebijakan Publik (Yogyakarta: Graha Ilmu, 2015)

Josephus A. Suatan, Tinjauan Terhadap Materi Peraturan tentang Kehidupan Beragama, (Litbang Jawa Barat, tidak diterbitkan untuk umum, tanpa tahun)

Komnas HAM: Stop Penutupan Gereja (Sinar Harapan 15/1/2008).

M. Nasir Tamara dan Elza Peldi Taher, eds., Agama dan Dialog Antara Peradaban

[Religion and The Dialogue between Civilizations] (Jakarta: Penerbit Paramadina, 1996).

Reform Review, Proyek Syariahisasi daerah (Vol I, No. 1).

Riant Nugroho, Public Policy (Jakarta: PT Gramedia, 2009), 39.Ippa Norris dan Ronald

Inglehart. Sekularisasi (Jakarta: Yayasan Abad Demokrasi, 2011)

Setiawan, "Konghucu dalam kemajemukan agama-agama" dalam Struggling in Hope, diedit oleh Suleeman,Sutama, Rajendra

Simatupang, Membuktikan Ketidakbenaran Suatu Mitos, 240. 